\title{
Reader Response Journals in Pre-service Instruction: Novice Teachers' Reflections on their Classroom Implementation
}

Janet E. McIntosh

Nipissing University

\begin{abstract}
The study described in this paper examines how five novice intermediate English language arts teachers implemented reader response journals, an instructional strategy they learned about in their pre-service English methods course. While using response journals in their classrooms, novice teachers provided student encouragement, thoughtful reflection on their approach, modification as needed, and a consistent positive attitude, even in the face of challenges. Study findings indicate that the theory and practice acquired in their pre-service course was beneficial to them, and that gaining confidence in themselves as teachers through further practice and experiences would enhance their effective use of this classroom strategy.
\end{abstract}

Key Words: pre-service teacher education; reflective practice; novice teachers

Janet E. McIntosh, Ed.D., is an Associate Professor of Education, in the Faculty of Education at Nipissing University in North Bay, Ontario. She teaches courses in intermediate/senior English language arts methods. Her research focuses on response to literature, implementation of reader response journals by both pre-service and novice teachers, and response strategies in classroom practice.

Email: janetm@nipissingu.ca 


\section{Reader Response Journals in Pre-service Instruction: Novice Teachers' Reflections on their Classroom Implementation}

\section{Theoretical Framework}

Introducing the reader-response journaling strategy is a challenge for English language arts classroom teachers. For novice teachers, with limited experience in the field, it can be an even more demanding task. Being exposed to varied strategies by their pre-service education professors, they have often learned both theoretical and practical aspects; upon program completion, they have decisions to make about which strategies to try with their own students. As an English educator, I've done extensive research on reader response journals in intermediate/senior English language arts classrooms and with pre-service teachers (McIntosh, $2003 ; 2006 a, 2006 b ; 2008)$. When introducing my education students to this strategy, I expose them to response theory and practice applications; they read professional articles and write their own journals. "I model an approach they could use in their own classrooms" (McIntosh, 2003, p. 33). Many novice teachers select this strategy for classroom use as it has captured their attention, has proven merits, and is one other teachers deem to be valuable for students. Once the strategy is chosen, they must carefully determine how to incorporate it into their classroom program. Grossman, Smagorinsky \& Valencia (1999) state the "need for teachers to experience a pedagogical approach from the standpoint of learner before they are able to implement this approach" (p. 20). The selected approach may be personal in nature, but in many cases, it is influenced by prior knowledge about the strategy acquired by pre-service teachers in their education courses. L'Allier \& Elish-Piper (2007) concur that one of the most effective ways "to help teacher candidates understand, value, and thoughtfully apply research-based practices in their student teaching and ultimately in their own classrooms is to have them experience and apply strategies in the coursework" (p. 339). Wilhelm (2008) perceptively explains:

Theory is involved in all that we do; theory can inform all that we plan to do so that we can do it better. So it is of vital importance to articulate our theories, to test them against our classroom experiences, to revise and use them in wide-awake ways. (p. 111)

\section{Context}

Understanding that the response journaling strategy is a valuable one, I encourage pre-service teachers to try it with students on practice teaching and in their own classrooms. In the past five years, some of my former education students, now $1^{\text {st }}$ year intermediate teachers, elected to introduce reader response journals in their English language arts programs. Thinking about my own approach to sharing the strategy with them, I wondered whether what I provided had been useful. How do I teach novice teachers effective approaches for reader response journals that reflect the theoretical frameworks which support the practice? Although I'd explained my success in using journals with students as a secondary English teacher, would this transfer into equal success with students in their classrooms? I was curious about novice teachers' implementation process. How did they choose to introduce reader response journals? Were they successful with their selected approach? How did they feel about the process and the student journal results?

In order to acquire some answers to these questions, I invited five novice teachers to participate in a study where they would verbally reflect on their response journal implementation 
process (McIntosh, 2006b). Through interviews, I asked them to share their experiences with first time use of reader response journals in intermediate English language arts classrooms. How do novice teachers' reflections on reader response journals indicate the successful implementation of approaches introduced during pre-service instruction? Articulating one's practice is a challenge, even for those who are seasoned teachers. Recognizing that these novice teachers' reflections would be insightful, I was confident that study findings would enhance aspects of their teaching. I also hoped to discover whether theory and practice in my pre-service courses was effectively transferred into classrooms by novice teachers.

\section{Method}

Five first year intermediate English language arts teachers who introduced reader response journals to their students are the study participants. As pre-service teachers in a northern Ontario Faculty of Education, they were enrolled in intermediate English language arts courses I taught in the past five years.

Upon course completion, I informed student teachers about my current research project and invited them to consider participating once they began teaching. Five contacted me and agreed to be interviewed about their response journal implementation process. All female participants teach in Ontario; three in the north and two in the south. Christine, Andrea, Amanda, and Nancy teach grade seven or eight Language Arts. Vicki teaches grade ten and twelve English.

The interview was used for data collection as it was an appropriate tool to "gather descriptive data in the subject's own words" (Bogdan \& Biklen, 1998, p.135); qualitative research methodology was used as it helped to explain the transcripts' contents. One 50 minute taped interview was conducted with each participant, outside of school hours and in their home community. These occurred in the second half of the school year, after participants had the opportunity to use response journals with their students for a period of time. A prepared set of questions served as a guide during interviews. Taped interviews were transcribed.

Each participant was assigned a number from one to five and transcript pages were numbered consecutively throughout. Using the constant comparative method to generate categories, emerging themes were identified; categories were then grouped together and analyzed. Pseudonyms were assigned for participants' names and the Faculty of Education.

\section{Findings}

Common categories revealed after transcript analysis include: approach used to implement response journals, reference to pre-service course, assessment/evaluation of journals, students' written journal responses, teacher's role, value of journals, future use of journals and examination of self as novice teacher.

\section{Approach used to implement response journals: Novices combine oral and written instructions.}

Christine's students "pick a couple of lines from a novel, say why they picked the quote and connect the quote to a theme, event or character." 
Andrea models response writing by reading aloud to her students and asking questions. During a class novel study of The Giver by Lois Lowry (199), students respond to a teacher prompt: "I had them pretend they were Jonas, and share a personal memory of their own." Amanda, Nancy and Vicki provide an introduction to response journals through oral and written statements. Amanda provides teacher modeling by reading aloud and states, "Here is how I might retell this passage." Students silently read their books for 15 minutes in daily language arts classes, then record responses.

As Nancy reads Treasure Island by Robert Louis Stevenson (1999) aloud to her language arts class, students listen; at the end of each chapter, "students would be given $5-7$ minutes for recording their response in the role they had selected."

Vicki's class uses journals for their biography/autobiography independent study unit. She defines response journals orally, and distributes a student handout. "The important thing was that they were writing it right after they had finished reading; it was immediate."

\section{Reference to pre-service course: Direct reference made to English language arts course.}

Christine states, "The merits of response journals, I learned at Northwood. I remember us talking about it's a chance to share their feelings...we read a really good article...I knew I wanted to implement them." She further explains, "I have them respond in the novel study that they were doing...trying to get them to do it like what we were hoping when we were at Northwood." Christine's understanding of appropriate journal use is acquired through knowledge from her pre-service course.

Andrea refers to the Tompkins (2002) course text, where she first heard about response journals. "Even the level of familiarity coming in...what I have heard about them so far...helped a bit in terms of a decision to use them or be aware of using them at all."

Amanda recalls how her peers in the course did "presentations on chapter books and retell as a strategy." She uses this in her classroom.

Vicki uses what she learned in her pre-service English course when she creates expectations for students' response journals. "I had them read, sort of like you did, I really did draw upon what you taught us." When students question the validity of response journals, Vicki explains:

I'd have to clarify a lot...give them that kind of support to let them know that this is valid...I would back up with things we learned in your class about why this is important, for them to connect to what they are reading.

Nancy states: "That's the only reason why I used reader response journals actually was because you suggested it and because of the articles and research you had done on it." Nancy wants to use journals with students based on her course experiences:

As a professor of English, I trust your opinion and your judgement...I figured that this was a really good way to get them to start having a relationship with text and not just as 'this is a book I have to read for English.'

Assessment/evaluation of journals: Novices question assessment techniques.

Christine states her uncertainty: 
Initially, I wasn't marking them because it's their place to respond...then I started to mark them... then I started levelling them, and now, they don't know, I put a level in my marking book and comments on their response journals.

When she first uses journals, Andrea says, "I did indicate that there was no right or wrong, that I wasn't actually grading in terms of a mark." She is concerned about "responding to them all, in addition to everything else." Conferring with her principal, who had used journals, she asks, "how did you manage it?... she had a sort of rotating schedule...she cycled and took a third, a third, so they knew that once every three weeks that they would expect their stuff to be looked at."

Amanda collects journals "once a week, on a Friday; after about 4 weeks of responses, (using rubric), then I give them a level...so that next week, they can work on some things to improve." She indicates, "I'm more comfortable with the comments, for sure, but you need to put a mark on it, too." As Amanda's pre-service professor, I assisted her with assessment tools:

I had that rubric, I had about five you gave me, I picked one that I really liked and I've used that consistently because I think it makes sense to stick to one and I don't want to start changing now 'cause I have a system that's working for me.

For Vicki's students' journal response project, they are "writing a total of 10 response journals that are due at two separate points, one half-way through the semester and the second closer to the end." Vicki explains: "I really like rubrics...I found it extremely time-consuming to read all of their response journals...but by using the rubric, as I'm reading them, I'm looking for these things."

Nancy's students respond after listening to her read aloud. Levels are assigned on a rubric; some criteria, students didn't meet. "Primarily it was detail. I find that they are not giving me enough." Students are required to demonstrate a "close, careful reading of the text, making personal connections, beyond plot summary, reflection on significant issues or themes of concern...a perceptive reading of the text."

\section{Students' written journal responses: Novice teachers share observations about what they read in response journals.}

Christine states "sometimes they catch me by surprise, and it just blows me away by what they'll write." She explains, "They won't interact with the text unless it's something that they are really interested in. But, if it's something that we did, that they just loved, I will get great responses."

Andrea states, "Some of them are surprisingly more articulate with some of their ideas than others. Sometimes the more personal it was, the easier it was for them to write." When reading The Giver, she had them pretend they were Jonas and write about a memory. "It was probably the best thing they did." She notes 'the moment' in their writing when they wrote "the one response they gave that was like wow."

Amanda's students' responses were "getting better as the year goes on." It seems that "the more they are enjoying the book, the deeper their responses." Amanda shares an example of a student who is "enjoying his book, relating to it, being inspired and recommending it to me."

Vicki comments that some of her students "naturally embraced it and did an excellent job." She faces challenges when she discovers that they didn't give the response journal strategy "enough credibility." Through Vicki's encouragement, she sees "progress over time. By the end of the process, they had started to embrace it a bit more." One of Vicki's students is "a bright 
kid but not really interested in school, more in socializing but with the response journals, he was one of the students that just immediately embraced it. His response journals are excellent."

Nancy was initially "a little bit disappointed. I had been talking to them about detail; support what you say...so I was disappointed with the amount of detail, the amount of elaboration they were giving me in that first set." Later on, she was "pleasantly surprised with many. They are reading into the text a lot more deeply, picking up on things that I don't think they would have been picking up on had they not been practicing, just trying to think, there was definite progression for most with their ability to respond."

\section{Teacher's role: Five novices speak.}

Christine explains that "when I didn't see what I would have liked from the beginning, I just tried to be encouraging and hoped they would just improve. And some of them have." Her role is to provide guidance:

I know that when I'm telling them to respond to an activity that we did, I said to them, don't tell me that you loved it if you don't. You're not going to get a good mark because you're saying 'Oh Yeah, Mrs. L., we loved what you did. I want you to tell me how you felt about it and why.

Andrea questions her approach: "Had I been responding to their journals on a regular basis, for a number of them, I would probably see more now." She later wonders about having to:

Caution myself, making sure that I don't respond so much so what they had written starts to become mine, you know, like taking it over. I think that they would appreciate that you identify with what they have written but you don't want to write so much, on the other hand, that it is no longer their special thing.

Amanda provides daily opportunities for writing. "I do English for an hour with them but about 15 minutes of the first hour I have them is response." Student book selection is guided by Amanda. "In my class, some of the students, it's mostly the boys have trouble finding novels that they enjoy...it's a challenge trying to find out what they are interested in, sports or whatever."

She believes that "they need to enjoy it, I think, if you're not enjoying it, then you're not going to be responding."

Vicki discovers that:

Some students really struggled with it...I would just coach them through it, I would have to clarify what I was looking for, and sort of give them that kind of support to let them know that this is valid.

Vicki explains that:

I would back it up with what we learned in your class and why it is important for them to connect to what they are reading and that they all have prior knowledge about topics and subjects they are reading about.

The teacher's role is not to simply implement the journals but to help students understand why the journal approach is appropriate. She says: "I believe, you know, when I was trying to convince them of why it was valid, I truly believed it."

As a grade eight teacher, Nancy feels responsible for preparing her students for secondary school. "It's a good starting point for them, to be delving into the novel and studying it and I wanted to hopefully give them a tool so they would be at a greater advantage in high school." Some students: 
Are not comfortable writing what they feel. Some are 'what do you want me to say and what do you want me to put in this?', and that defeats the whole purpose of a personal response...so it's actually teaching them how to respond.

\section{Value of journals: Novice teachers articulate benefits.}

Christine notes "when I see the spots, you know really great insight coming in, I think, I would like to, I feel that maybe more of them are capable of that if they had the chance to write more often." Students benefit from daily writing. "I think they are important. I think it'll help them write better essays and better opinion pieces, better everything."

Andrea observes that "I could get more information from looking at their journals and reading them than they were prepared to give...it gives me a view into...sometimes it gives me what they don't give me orally." She adds, "there is so much emphasis on having the kids make personal connections...I find that it's such as easy or natural way to give them a moment to have them make that connection."

After a few months, Amanda's students exhibit greater engagement. "Sometimes they say they need more time, you know, when I say in a few minutes we are moving on to Geography, their hands go up that they need more time so they are writing more." She believes journals are a "valuable part of the Language Arts program because it teaches students to take responsibility for their own reading, to find things that they enjoy reading, and hopefully instils the love of reading in them."

Vicki values students using journals to "connect to what they are reading...when prior knowledge is activated, and that's where the meaning of a piece of literature comes from." She explains the 'act of reading' to her students and encourages them to see this as "an opportunity to write about things that are leaving an impression on you." Nancy tells her students, "your opinion is what matters to me and I want to know what you think about this." The value of response journals is summarized by Nancy: "It's validating a person's own response to text, and to me, that's the best place to start creating with the text as opposed to what does the teacher think, because it's a never ending battle where you are trying to decode."

\section{Future use of journals: Five novices desire to continue journal use.}

Christine states "I definitely want to use them again... I think they are valuable. I want to try to find a way to get them (the students) to use then more regularly though." She says, "I think I can get the grade eight teacher for next year to use them; he's new, too and he'll be doing my seven's for Language and I'm sure he'll carry on with it."

In the future, Andrea "would like to respond to them more. She wants to "collect them more often and probably on a rotating basis." Andrea considers other stimulus for responses. "There are so many things to have them respond on. I always thought of but haven't done much of it this year, to do more of a current events kind of thing..."

Amanda states "I would like to try maybe more of a friendly kind of journal where you (the teacher) respond back and forth, you know, with comments and questions." She says:

I think I might even send a letter home at the beginning of the year to parents about what we are going to be spending time on in Language Arts and this will be part of our program...to encourage the students, to read at home. 
Vicki would "probably start by expecting that they know nothing about response journals in the form that we are teaching them and then go from there." Having used the journaling strategy with grades ten academic students, she says, "I guess my next step would be to implement it in an applied or maybe a grade 11 College class." Vicki has no hesitation in using journals again; "I think it's great...I believe in it, for sure, I'd use them again."

Nancy explains, "It forced the students to pay attention to what was going on in the text...in order for them to pull a quote, they had to know what was leading up to and coming after that quote." Her approach is beneficial and when using journals again, she states, "if I was teaching at this level, I would still keep them structured; I found that worked to my advantage and to their advantage."

\section{Examination of self as novice teacher: Novice teachers as learners.}

Christine says "I don't have my program working well enough so that I can get them to use them (journals) as often as I would like." Christine feels she needs:

To get a lot more comfortable with it. As a first year teacher, I believe in it and will still continue to believe in it but really, you doubt yourself, you wonder whether it's something you've done that isn't making it right...you know, it's a matter of time.

Andrea's statement, "I haven't done it, mostly, you know being a new teacher, I haven't learned yet," presents herself as a novice. She asks: "Am I not doing it right? Is there a right way and should I be doing that all the time? "Andrea thinks about her process.

Considering her students' experience with journals, Amanda says:

I think it becomes clearer once they started doing it...I have more knowledge of how to do it, too so it was my first time with it, teaching the response journal, ever, so I probably could have been more clear.

Amanda states, "I write journals at home...personal writing. I've found that I reflect more on my teaching and writing down things that worked and didn't work."

Recalling a discussion in her pre-service course about the usefulness of rubrics, Vicki honestly reflects: "I think you can evaluate with them, you know, so I kind of shifted my opinion on that, I used to be somewhat sceptical." Vicki used journals with one class but:

If I were teaching $2 \mathrm{P}$ again, even if it was a struggle for them, it would be worth taking the risk, even if it didn't work exactly. I think in my first year teaching, I wasn't maybe willing to take as much of a risk you know, now that I've gone through it, I am willing to do it.

Vicki exhibits an increased confidence in this passage.

Nancy reveals that she is a learner, as a novice teacher. She notices that "not all gave exactly what I was looking for but I find that as a new teacher, that's something I am learning." Nancy read aloud to her students because:

I loved being read to as a child and I find that the reality is a lot of students aren't reading whenever you are assigning reading to them, so I read to them, yes...I took it as an opportunity for them to hone in on their listening skills.

She compares her experience as a student reader, to that of her students:

It's OK to have a personal response...that's OK that you hate the book but tell me why you hate it...I remember growing up and studying books and thinking you have to like it because your teacher told you to study it but in my opinion, that's not necessarily true. 
Nancy shows empathy for students. Her experience using reader response journals with her students is "a learning process for me."

\section{Discussion}

In reflecting on the implementation process, novice teachers shared their classroom experiences with intermediate students using reader response journals for the first time. Both teachers and students were learning together. For the students, they were aware of journals but not reader response journals and for their teachers, the act of using this strategy with grades seven to ten students was a new one. There was no question about teacher commitment to journals but they recognized that this attitude was only a starting point. All were conscious of the need to focus on an effective approach to bring about desired journal results based on their understanding of the strategy. Although their approaches differed, what they shared was their decision to use response journals with students, a strategy they had learned about in their pre-service program. Reader response theory was introduced in their course; they applied the theory through practical application of writing a personal journal.

As an English educator/researcher, I believe that a substantial theoretical component is required in teacher education programs (McIntosh, 2006b, p. 25). Student teachers need opportunities for discussion of a theory's practical implications; these should be embodied and modeled in the program and so experienced first-hand by the student teachers (Beck, Kosnik \& Roswell, 2007). New teachers' views on the preparation they most needed in the first year of teaching are the focus for Beck et al.'s study; participants reported "acquiring many useful teaching strategies, activities and materials" (p. 59) in their program. Britzman (2003) states that, "Prospective teachers want and expect to receive practical things, automatic and generic methods for immediate classroom application" (p. 63). With regard to this study, the reader response journal was practical in nature. Teachers referred to course discussions on theoretical readings, handouts provided and journal writing they completed in their pre-service course at Northwood. But what they were given wasn't prescriptive, or step-by-step, like a "recipe" (p. 65) which Britzman indicates new teachers search for in teacher education programs. Christenbury (2006) writes that "no class or book can teach a beginner or novice what to do and how to do it in every specific instructional incident" (p. 44). Novice teachers in this study needed to try the journaling strategy on their own, modify it as required and meet challenges as they arose. Personal classroom experiences with students helped them assess the effectiveness of their approaches.

One challenge faced by novices related to evaluation of journals. Using rubrics or comments, they were determined to make the assessment authentic but knew that it could be somewhat subjective. They experimented with varied techniques and selected one which worked best for their students and themselves. These new teachers, like Beck et al's study, were exposed to assessment tools in pre-service and they had resources but they still had some uncertainty. One participant in that study spoke of "the challenge of the regular first-year teaching load, keeping up with the marking, trying to avoid marking too little but also marking too much" (p. 68). Similar comments were made by novice teachers in this study. Their decision to evaluate response journals may have been influenced by a belief which was shared in our course. My research (McIntosh, 2003) reveals that for journals to be an integral part of the classroom program, they need to be assessed. Students do not have the same commitment to writing them if they are simply assigned a 'complete' or 'incomplete'. 
Another challenge related to the fact that student response journal content was not what the teachers expected. Prior to assigning journals, novice teachers had a view, in their own minds, of how journal results would look. In practice, students didn't always meet these expectations. Sometimes teachers questioned themselves about whether instructions were clear or whether they were using the strategy right. Christenbury's (2006) research supports this characteristic of novice teachers. "Another aspect of teaching, especially beginning teaching, is the seductive - but false - idea of teaching as correct and incorrect. Beginning teachers...tend to think in terms of right and wrong when it comes to classroom practice" (p. 73). Study data reveals that when teachers provided consistent encouragement, allowed time for students to practice and gain confidence in their response writing, this resulted in more effective journaling. Although novice teachers faced challenges in their implementation process, they had a clear view of their role. They consistently set out verbal expectations, and some gave student handouts. Throughout the journaling process, guidance was provided. When journals were evaluated, teachers gave student feedback to support improvement in written responses. All novice teachers had a positive attitude about using the journals which was displayed in their desire to implement them in classrooms. The journal's value was conveyed to students. Reader response journals did provide ideal opportunities for student writers to engage with text. Glenn (2007) states, "asking students to participate in reader response to literature through writing has been shown to further support comprehension by allowing students to reflect carefully and deliberately on the meaning they might derive from a text" (p. 11). Effectively integrating reading and writing experiences is a goal in language arts classrooms; writing a response journal while reading a text is an ideal way of achieving this. "The act of writing responses in a journal invites students to become actively involved in their reading; teacher-created questions are not the focus" (McIntosh, 2006a, n.p.). Novice teachers voiced a desire to use reader response journals with future classes and had suggestions about possible changes in their approaches. Although they clearly conveyed the demands of initial implementation, they weren't willing to abandon this classroom strategy.

Examining oneself as a novice teacher is an intriguing category. Each teacher honestly shared their feelings about being new to the teaching profession. At times, they question their approach to implementation; when the results weren't exactly what they expected, they wondered whether they were using the strategy correctly. Their uncertainty came through in statements about "being new" and "needing time to practice" which indicated some self doubt. Novice teachers had definite views, likely acquired in pre-service English language arts courses which influenced their classroom approaches. Daily challenges were often associated with how to begin and sustain the implementation process. With their limited classroom experience, they each had less than one year to gain confidence in their ability to use the strategy effectively. Time is needed for a novice teacher, or any teacher for that matter, to use a particular strategy for the first time. Wilhelm (2008) writes: "What is true of all learners is true of teachers - we need to take risks, make mistakes, have help, reflect and we need to give ourselves the time to do this and we need to do all of this over time" (p. 59). Feiman-Nemser (2001) states that "no matter what kind of preparation a teacher receives, some aspects of teaching can only be learned on the job...novices [need] to figure out what works for them as they construct their own professional practice and identity" (p. 18-20). 


\section{Conclusion}

Study findings reveal that novice teachers seemed to be particularly demanding of themselves. In their determination to make the response journals work effectively in classrooms and for their students, they set high expectations. Although this study's focus was response journal implementation, on a daily basis, these teachers used many new strategies. Being a novice in the teaching field was a challenge in itself. Novice teachers had the opportunity to reflect on their classroom practice through interview questions. Although many teacher education programs introduce the concept of teacher as reflective practitioner (Schon, 1987), the reality is that for most teachers in the field, time for reflection is quite limited.

Penso, Shoham \& Shiloah's (2001) study examines the ability of novice teachers to reflect on their practical experience. Their study results "emphasized the need to consider ways of creating opportunities to develop reflective thinking among novice teachers to promote their professional growth" (p. 323). My interview questions provided a chance for reflective thinking as novice teachers were asked to articulate classroom practice. It's possible they were critical of their actions in the classroom, especially since their pre-service professor was the one asking them to share. As I listened to their responses, they explained what worked well, the various challenges they faced and how they might change their approach with future classes. I thought of how my former students were now developing as teachers, with their own students to guide. While transcribing taped interviews, I heard their individual voices; they were articulating theoretical knowledge and how they had applied it in a practical way in classrooms. Following the interviews, they mentioned that they appreciated the opportunity to talk about their use of response journals. Even as novice teachers, they saw the value in such a practice.

Although I'm an experienced English educator/researcher, I still view myself as a learner. Findings of this current study allow me to reflect on my own practice, and consider how what I teach in pre-service courses helps prepare beginning teachers for the realities of the classroom. Beck et al. (2007) states that such a study "suggests lines of thought and practice for teacher education...helps us to understand the challenges new teachers face and do better what to a large extent we are already doing to assist them" (p. 55). What can I do to best prepare my preservice English language arts teachers for their own classrooms? How can I provide both theory and practice in a balanced way so that they can effectively apply them beyond the Faculty of Education? Although the pre-service program provided the groundwork for building successful classroom experiences, confidence increases as teachers expand their knowledge, skill and expertise in the early years of teaching. Growth over time is the desired outcome. I consider the possibility of tracking these novice teachers into their $2^{\text {nd }}$ or $3^{\text {rd }}$ year of teaching, asking them about how their response journal implementation has changed and the reasons they considered in making these changes. Future research might clarify this issue. Or perhaps, it will reveal more questions for me to ponder. As Christenbury (2006) says, "Teachers, in order to teach, really must continue to learn" (p. 123). This is an understanding I share. 


\section{References}

Beck, C., Kosnik, C., \& Rowsell, J. (2007). Preparation for the first year of teaching: Beginning teachers' views about their needs. The New Educator, 3(1), 51-73.

Bogdan, R. \& Biklen, S. (1998). Qualitative research for education: An introduction to theory and methods ( $3^{\text {rd }}$ ed.). Boston, MA: Allyn and Bacon.

Britzman, D. (2003). Practice makes practice: A critical study of learning to teach (Rev. ed.). Albany, NY: State U. of New York Press.

Christenbury, L. (2006). Making the journey: Being and becoming a teacher of English language arts $\left(3^{\text {rd }}\right.$ ed.). Portsmouth, NH: Heinemann.

Feiman-Nemser, S. (2001). Helping novices to learn to teach: lessons from an exemplary support teacher. Journal of Teacher Education, 52(1), 17-30.

Glenn, W.J. (2007). Real writers as aware readers: Writing creatively as a means to develop reading skills. Journal of Adolescent \& Adult Literacy, 51(1), 10-20.

Grossman, P.L., Smagorinsky, P., \& Valencia, S. (1999). Appropriating tools for teaching English: A theoretical framework for research on learning to teach. American Journal of Education, 108(1), 1-29.

L'Allier, S. \& Elish-Piper, L. (2007). "Walking the walk" with teacher education candidates: Strategies for promoting active engagement with assigned readings. Journal of Adolescent \& Adult Literacy, 50(5), 338-353.

Lowry, L. (1999). The Giver. Mississauga, ON: Random House.

McIntosh, J.E. (2003). Pre-service teachers' attitudes about implementing reader response journals in senior English classrooms. English Quarterly, 35(3, 4), 32-37.

McIntosh, J.E. (2006a). Enhancing engagement in reading: Reader response journals in secondary English classrooms. Language and Literacy, 8(1). Retrieved from www.langandlit.ualberta.ca

McIntosh, J.E. (2006b). Reflection on the process of implementing reader response journals in the grade 7 and 8 language arts classrooms of novice teachers. The Reading Professor, 28(1), 24-31.

McIntosh, J.E. (2008). Reader response journals in intermediate Language Arts: Reflection on the implementation process. English Quarterly, 38(2-3), 16-21.

Penso, S., Shoham, E., \& Shiloah, N. (2001). First steps in novice teachers' reflective activity. Teacher Development, 5(3), 323-338. 
Schon, D.A. (1987). Educating the reflective practitioner. San Francisco: Jossey-Bass.

Stevenson, R.L. (1999). Treasure Island. Toronto: Pearson.

Tompkins, G., Bright, R., Pollard, M. \& Winsor, P. (2002). Language Arts: Content and teaching strategies $\left(2^{\text {nd }}\right.$ Canadian ed.). Toronto, ON: Pearson.

Wilhelm, Jeffrey. (2008). "You gotta BE the book": Teaching engaged and reflective reading with adolescents ( $2^{\text {nd }}$ ed.). New York: Teachers College Press. 